\title{
Kramářské písně interdisciplinárně
}

\section{Do Brna široká cesta. Kramářské písně se světskou tematikou. Katalog k výstavě.}

Ed. Hana Glombová. Brno: Moravské zemské muzeum. 2020. $128 \mathrm{~s}$.

ISBN 978-80-7028-532-9

Na podzim minulého roku byla v Moravském zemském muzeu zahájena výstava s názvem Do Brna široká cesta. Kramářské písně se světskou tematikou, na jejíž přípravě se podíleli pracovníci čtyř pracovišt, konkrétně z již jmenovaného muzea, dále z Etnologického ústavu AV ČR, Filozofické fakulty MU a Moravské zemské knihovny. Cílem výstavy bylo přibližit veřejnosti nové poznatky o světských kramářských písních, a to z různých aspektů - literárního, jazykového, historického, folkloristického aj.

Při př́ležitosti výstavy byl vydán katalog, který představuje spojení klasického výkladu s prezentací vystavených předmětů. Již v úvodu mohu předeslat, že jde o kombinaci zdařilou. Zatímco první polovina katalogu má formu kratších odborných pojednání, v nichž jsou postupně představena vybraná témata spjatá s problematikou kramářských písní, druhá část, tradičně katalogová, obsahuje celostránkové fotografie exponátů (např. starých tisků, špalíčků, hudebních nástrojů, dobové snímky potulných zpěváků atd.), jejich popisek s informacemi o původu a současném uložení a také zasazení objektu do širšího kontextu dobové tištěné (potažmo písňové) produkce. Katalog díky podrobným textům připojeným k obrázkům může sloužit samostatně, tedy nezávisle na výstavě, což je žádoucí obzvláště v době, kdy je většina akcí obdobného charakteru kvůli epidemiologickým opatřením uzavřena veřejnosti.

Středobodem publikace jsou, jak bylo zmíněno, kramářské písně se světskou tematikou. Dočteme se, že písně daného typu jsou vydělovány na základě funkce - jejich cílem bylo zprostředkovat posluchačům informace rozličného charakteru a pobavit je. Některé písně mají blízko k dnešní žurnalistice, zvláště té bulvární, jiné směřují k duchovním písním (zejména písně o zázračných uzdraveních). Pro mnohé texty je charakteristická žánrová kontaminace, odrážející se i na jazykové rovině. Kramářské písně nejsou fenoménem výhradně českým, lze je vystopovat i u dalších národů, kde se pro ně vžily různorodé názvy jako broadside ballads (angl.), Bänkelsang, Flugblattlieder či Lieddrucke (něm.), cantastoria (ital.), pieśni straganowe (pol.) aj. V dalších kapitolách je čtenář přenesen do tiskařské dílny a obeznámen např. s předpoklady pro komerčně úspěšný tisk nebo s dobovou cenzurou. Dozví se rovněž o dalším osudu již vytištěného tisku, tj. o jeho prodeji a prezentaci na jarmarcích a poutích. Detailně je probrán jazyk tisků a jejich grafika, též bohatá škála témat a opakujících se motivů. Bez zajímavosti není ani poslední kapitola, v níž je upozorněno na pokračující linii kramářských písní do současnosti, respektive některých jejich prvků, jako je výstavba textu, melodie či performance.

V katalogu jsou čtenáři přibližzeny světské kramářské písně jako celek, tj. jako žánr v jistém období značně oblíbený u určitých vrstev obyvatelstva, místy se do popředí dostávají jednotliviny, které překvapí až kuriózním obsahem, jež mohou být - s přispěním 
svérázné stylizace dobového jazyka - pokládány za zajímavé, ne-li humorné i pro současného čtenáře.

Při šíři zorných úhlů, z nichž je v katalogu na písně nahlíženo, je pochopitelné, že autoři nemohli ve výkladech zacházet do detailů, z toho důvodu mohou některé závěry a formulace působit jako zjednodušené. Vzhledem ke své specializaci tu uvedu dvě drobnosti spojené s rozborem jazyka písní. Nelze souhlasit s hodnocením některých jazykových jevů jakožto typických pro „texty nižšího stylu“, pronikající do jazyka textů vysokého stylu konce 16. století prý „jen nepatrně“ (s. 20). Např. náslovné ou- (v grafice au-) bylo zpočátku dozajista stylisticky příznakovým jevem (oproti pozici uvnitř slova a v koncovkách), ale už od 3o. let 16. století se začínají doklady s provedenou diftongizací množit napříč všemi žánry (PoRÁk 1983 , 109), ve 2. polovině 16. stol. se podoby s diftongem „stávají stále běžnější a většina slov je doložena s au- nebo s kolísáním obou podob“ (tamtéž, s. 113). O stylovou diferenciaci v případě náslovného ou- jde pouze v př́padě okruhu kralických tisků, zasloužila se o ni zvláště tzv. Jednodílka z roku 1613, v níž byl dřívější diftong záměrně nahrazován grafémem $v$ ve snaze o zvýšení exkluzivity biblického jazyka (DiTTMANN 2018, 106). Na skutečnost, že ou- nebylo znakem jazyka textů nižšího stylu, bylo ostatně upozorněno na konferenci, která byla konána v rámci projektu zaštitujícího mj. uspořádání výstavy a vydání katalogu; J. Pleskalová a O. Navrátilová tu představily jazykový rozbor kramářských písní 17. a 18. století, jímž přesvědčivě vyvrátily některé předsudky s tímto literárním okruhem spojené (prezentace př́spěvku je dostupná on-line). Druhá poznámka se týká infinitivu zakončeného na -t', jenž byl do jevů „společných velké části hanáckých dialektů“ (s. 22) zařazen patrně omylem; infinitivní - $t$ ' bylo prokazatelně doloženo jen pro severovýchodní okraj tradičních středomoravských nářečí (ve starší terminologii hanáckých), navazující tak na rozsáhlejší oblast nářečí východomoravských a slezských (v nich -t' podléhalo asibilaci). Dokazuje to jak příslušná mapa v Českém jazykovém atlasu (konkrétně položka jet), tak např. mapa v monografii Nářeči Určic a okolí F. Kopečného. Lze namítnout, že pro tisky ze 17. a 18. století lze teoreticky předpokládat širší areál daného hláskového jevu, bohužel se tu však nemůžeme opř́it, pokud je mi známo, o konkrétní data.

Tyto dvě drobnosti nijak neubírají na hodnotě představeného katalogu, jehož hlavním př́nosem je mezioborová prezentace kramářské písňové tvorby jakožto fenoménu jisté doby a jistého společenství. Doufám, že spolupráce odborníků, kteří spojili své síly při tvorbě katalogu a uspořádání výstavy, bude pokračovat i v budoucnu a že se můžeme těšit na další zdařilé projekty.

\section{LITERATURA}

Český jazykový atlas [online; 2., elektronické, opravené a doplněné vydání] (2012-2016). Brno: Akademie věd České republiky, Ústav pro jazyk český. Dostupné z: http://cja.ujc.cas.cz [pdf verze], <https://cja.ujc.cas.cz/e-cja> [html verze; dosud 1.-4. díl]. 
Ditтmann, Robert. 2018. Vokalismus Bible kralické šestidílné II. Uplatnění změn proběhlých od konce 14. století. Listy filologické 141 (1-2), 95-130.

KopeČnÝ, František. 1957. Nářečí Určic a okolí. Praha: Nakladatelství Československé akademie věd.

NAVRÁtilová, Olga - Pleskalová, Jana. 2019. Language of broadside ballads from the $17^{\text {th }}$ and $18^{\text {th }}$ centuries [online]. Brno: Masarykova univerzita. Dostupné z: https://www.phil.muni. cz/media/3166509/navratilova_pleskalova_language_of_the_broadside_ballads.pdf.

PoRÁk, Jaroslav. 1983. Humanistická čeština. Hláskosloví a pravopis. Praha: Univerzita Karlova.

Poděkování: Příspěvek vznikl s podporou dlouhodobého koncepčního rozvoje Ústavu pro jazyk český AV ČR, v. v. i., RVO: 68378092.

\section{Marta Šimečková}

Czech Language Institute of the CAS, v. v. i.

Veveří 97, 602 oo Brno

Czech Republic

simeckova@ujc.cas.cz 